Volume 1 Issue 2, November 2018, Page 7-18

P A LREV | J O U RNAL O F LA W

ISSN : 2622-8408 - E-ISSN 2622-8616

PAMULANG

L A W REVIE W

\title{
KONTROVERSI KEBIJAKAN KRIMINAL PEMERINTAH TENTANG PRAKTEK SANKSI KEBIRI BAGI PELAKU KEJAHATAN SEKSUAL
}

\author{
Amrizal, Feri Kurniawan, Ichwani Siti Utami \\ Universitas Pamulang \\ amrizalsiagian@yahoo.com
}

\begin{abstract}
Castration sanctions for perpetrators of sexual crimes are the product of governmental criminal policies as an effort to overcome sexuals crimes, especially sexual crimes againt children. The chemical castration policy and the installation of electronic detection devices are expected to give deterrence to the perpetrators and creat a sense of security for the community and at the same time show that the state (goverment) is present and seriously takes care of this crime. The issuance of PERPPU 1/ 2006 is intended to revise the previous (UU No. 3 Tahun 2002 tentang Perlindungan Anak) by further increasing sanction for perpetrators sf sexual crimes. The issuance of PERPPU 1/ 2006 was not quiet form the debate between giving severe sanctions to the perpetrators with the consepts of human rights, between the medical code of ethics and the executor in the field and between legal facts and the social cultural conditions of community. So that many parties doubt the effectiveness of the castration sanction. Despite controversy, the practice of castration sanctions will be a measure of the government's success in overcoming sexual crime and the explore criminal policy cebates that are still in the controversy are focused on evaluating policies and considering their positive values and benefits.
\end{abstract}

Keywords: criminal policy, government, castration, sexual crime

\begin{abstract}
ABSTRAK
Sanksi pengebirian bagi pelaku kejahatan seksual adalah produk dari kebijakan kriminal pemerintah sebagai upaya untuk mengatasi kejahatan seksual, terutama kejahatan seksual terhadap anak-anak. Kebijakan pengebirian bahan kimia dan pemasangan alat pendeteksi elektronik diharapkan memberikan pencegahan bagi para pelaku dan menciptakan rasa aman bagi masyarakat dan pada saat yang sama menunjukkan bahwa negara (pemerintah) hadir dan secara serius menangani kejahatan ini. Penerbitan PERPPU 1/2006 dimaksudkan untuk merevisi sebelumnya (UU No. 3 Tahun 2002 tentang Perlindungan Anak) dengan semakin meningkatkan sanksi bagi pelaku kejahatan seksual. Penerbitan PERPPU 1/2006 tidak sepi dari perdebatan antara memberikan sanksi berat kepada pelaku dengan konsep hak asasi manusia, antara kode etik medis dan pelaksana di lapangan dan antara fakta hukum dan kondisi sosial budaya masyarakat. Sehingga banyak pihak yang meragukan efektivitas sanksi pengebirian. Terlepas dari kontroversi, praktik sanksi pengebirian akan menjadi ukuran keberhasilan pemerintah dalam mengatasi kejahatan seksual dan eksplorasi kebijakan kriminal yang masih ada dalam kontroversi difokuskan pada evaluasi kebijakan dan mempertimbangkan nilai serta manfaat positifnya.
\end{abstract}

Kata kunci: kebijakan kriminal, pemerintah, pengebirian, kejahatan seksual 


\section{PENDAHULUAN}

Peristiwa tragis gadis siswi SMP di Lampung bernama Yuyun, menunjukkan dugaan bahwa masyarakat tidak mengira, dan sekaligus sangat kaget, dan tidak menyadari bahwa ada sebagian masyarakat hidup tanpa norma (normlessness) atau masyarakat tadi gagal mengatur nafsu alamiah individunya (Siagian, $2015: 3$ ).

Kekagetan peristiwa sadis tadi, bersambung cerita dengan kejadian yang hampir sama dengan peristiwa kejahatan seksual yang dilakukan oleh sekelompok "predator" atas sejumlah murid-murid di sekolah Internasional (JIS Jakarta) dan kasus pedofilia Andri Sobari alias Emon yang menelan korban 73 orang anak. Peristiwa kejahatan seksual tadi, menciptakan rasa takut terhadap masyarakat, terutama para orang tua akan pergaulan dan interaksi anaknya terhadap orang-orang di sekitarnya, para orang tua mengalami paranoid dan rasa was-was atas pergaulan anak-anaknya. Saat ini, dan kuat dugaan, pelaku kekerasan seksual terhadap anak ini ibarat gunung es (ice berg), yaitu terlihat kecil di permukaan namun besar di dalam. Kasus kekerasan seksual anak di Indonesia dari tahun ke tahun mengalami peningkatan. Data Komisi Pelindungan Anak Indonesia (KPAI) menyebutkan bahwa pornografi, kekerasan seksual, dan eksploitasi seksual komersial pada anak, pada tahun 2011 tercatat sebanyak 329 kasus, atau 14,46 persen dari jumlah kasus yang ada. Sementara tahun 2012 jumlah kasuspun meningkat sebanyak 22,6 persen menjadi 746 kasus. Kemudian di tahun 2013 sampai dengan bulan Oktober, kekerasan seksual pada anak yang dipantau mencapai 525 kasus atau 15,85 persen. Data ini diperoleh melalui pengaduan masyarakat, berita di media massa, dan investigasi kasus kekerasan seksual anak. Dan mayoritas korban kekerasan seksual adalah anak lakilaki dengan perbandingan persentase 60 persen laki-laki dan 40 persen perempuan. Sementara profil pelaku di hampir semua kasus merupakan orang terdekat anak, bisa jadi guru, paman, ayah kandung, ayah tiri, dan tetangga. (Kompas.com. (2014). Komisi Perlindugan Anak Indonesia (KPAI): Kejahatan Seksual terhadap Anak-Anak adalah Bencana Nasional). Perlu adanya perlindungan Hak Asasi Manusia yang komprehensif menyeluruh untuk keberlangsungan kehidupan masyarakat luas (Rezky, 2018:3).

Dengan kondisi kejahatan seksual seperti tadi, dan menjadi alasan kuat tentang bahwa terbitnya kebijakan kriminal pemerintah tentang kebiri (dalam PERPPU Nomor 1 Tahun 2016) terhadap pelaku kejahatan seksual sebagai sebuah pilihan rasional. Mengingat bahwa kebijakan kriminal (criminal policy) adalah sebagai usaha rasional masyarakat dalam menanggulangi kejahatan, yang secara operasional dapat dilakukan baik melalui sarana penal maupun sarana non penal. Kedua sarana ini (penal dan non penal) merupakan suatu pasangan yang satu sama lain tidak dapat dipisahkan, bahkan dapat dikatakan keduanya saling melengkapi dalam usaha penanggulangan kejahatan di masyarakat. Dan penanggulangan kejahatan melalui sarana penal lazimnya secara operasional dilakukan melalui langkahlangkah: perumusan norma-norma hukum pidana, yang di dalamnya terkandung adanya unsur substantif, struktural, dan kultural masyarakat di mana sistem hukum pidana itu diberlakukan. Sistem hukum pidana yang berhasil dirumuskan itu selanjutnya secara operasional bekerja lewat suatu sistem yang disebut Sistem Peradilan Pidana (Criminal Justice System) (Undip, 
1995 : 7). sebagaimana pidana peng kebirian.

Beberapa respon segmen masyarakat tadi, bahwa praktek hukum kebiri bagi pelaku kejahatan seksual terhadap anak-anak bukanlah satu-satunya strategi penanggulangan kejahatan seksual yang harus terus menerus didukung dan tetap dipertahankan. Namun untuk saat ini, terbitnya PERPPU Nomor 1 Tahun 2016 tentang Perlindungan Anak, utamanya sanksi kebiri adalah salah satu yang rasional dilakukan pemerintah, untuk mengatakan bahwa negara hadir, meskipun keberlakuan hukumnya masih kontroversial.

\section{METODE PENELITIAN}

Metode penelitian yang digunakan adalah metode penelitian deskriptif analisis yakni dengan memaparkan data yang ada kemudian dianalisis dalam memecahkan permasalahan yang ada, dan juga menggunakan studi kepustakaan (Library Research) untuk mengumpulkan data sekunder. Dalam konteks penelitian, metodologi adalah totalitas cara untuk dapat meneliti dan menemukan suatu kebenaran yang tidak hanya mengacu pada metode penelitian tetapi juga terhadap paradigma, pola pikir, metode pengumpulan dan analisa data, hingga cara penafsiran dari penemuan penelitian itu sendiri. Oleh karena itu, metodologi tidak hanya berkaitan dengan tehnis pengumpulan data namun juga menyangkut rasionalitas (alasan-alasan) mengapa seluruh hal yang sifatnya tehnis tersebut sangat perlu dilakukan.

Ragamnya metode penelitian yang ditawarkan para ahli untuk menganalisa setiap permasalahan dalam kajian ilmiah, mendorong penulis memakai metode Evaluatif untuk menganalisa kajian yang sedang diteliti. Metode Evaluatif ini sering digunakan untuk melihat tingkat keberhasilan sebuah kebijakan. Penelitian evaluasi merupakan suatu proses yang dilakukan dalam rangka menentukan kebijakan dengan terlebih dahulu mempertimbangkan nilai-nilai positif dan keuntungan suatu program, serta mempertimbangkan proses serta tehnik yang telah digunakan untuk melakukan penilaian. (Arikunto, 2005: 222)

Penelitian ini menggunakan beberapa teknik pengumpulan data; pertama, analisa dokumen; dipergunakan untuk menelaah data yang telah ada, baik yang berupa dokumen-dokumen kebijakan, makalah, jurnal, atau buku-buku hasil penelitian sebelumnya yang relevan. Kedua, wawancara mendalam. Dokumen merupakan catatan peristiwa yang sudah berlalu. Dokumen yang dianalisa dalam penelitian ini berupa peraturan atau kebijakan yang berkaitan dengan masalah yang hendak diteliti, baik melalui penulusuran pada lembaga-lembaga terkait, buku-buku maupun artikel-artikel yang membahas tentang permasalahan sanksi kebiri.

Pada penelitian ini, penulis banyak memanfaatkan buku-buku yang terkait dengan tema penelitian, kliping-kliping atau artikel-artikel yang dimuat diberbagai media massa. Selain itu dengan buku-buku hasil laporan ataupun hasil laporan-laporan penelitian.

Kedua, wawancara mendalam (depth interview). Tujuan penggunaan metode ini adalah untuk mengenal nara sumber (untuk selanjutnya disebut informan), mengeksploitasi realitas yang ia miliki, dan mengetahui makna-makna apa yang ia berikan terhadap isu yang ia teliti. Dalam hal ini, peneliti menempatkan diri dalam posisi informan yang diwawancarai, untuk mendapatkan pemahaman terhadap proses-proses berpikir dari informan. Adanya relasi antara peneliti dan informan 
merupakan salah satu ciri sekaligus membedakan wawancara mendalam yang merupakan tipe tradisional dari unstructured interview dengan tipe wawancara lainnya dalam kategori structured interview. Penelitian dengan menggunakan pendekatan sistematika norma hukum (statute approach dan studi perpustakaan. Penelitian hukum dengan pendekatan perundang-undangan dilakukan dengan cara memahami, mengungkap dan menafsirkan makna norma-norma hukum yang menjadi bahan hukum penelitian. Norma-norma hukum itu dipahami, diungkap dan ditafsirkan maknanya dengan penafsiran yang ada dalam ilmu hukum.

\section{PERMASALAHAN}

Adapun agar memberikan arahan terhadap penulisan ini, maka penulis membatasi ruang lingkup permasalahan pada bagaimana Kebijakan Kriminal Dalam Rangka Mencegah Kejahatan Seksual ? dan Bagaimana Kontroversi Sanksi Kebiri dalam PERPPU No. 1 Tahun 2016 tentang Perlindungan Anak?

\section{PEMBAHASAN}

Istilah kebijakan berasal dari kata "Policy" (Inggris) atau "Politiek" (Belanda). Bertolak dari pengertian tersebut, maka kebijakan hukum pidana dapat juga disbut sebagai "Politik hukum pidana". Dalam kepustakaan dikenal dengan berbagai istilah yakni "Penal Policy", Criminal Law Policy", atau "Straffrechtspolitiek". Kebijakan kriminal adalah suatu bentuk kebijakan yang diambil oleh negara untuk melakukan kriminalisasi terhadap suatu tindakan yang dianggap merugikan, serta strategi untuk menanggulanginya. Dengan merujuk pada tiga peran utama dari kebijakan: pembuatan kebijakan, pelaksanaan kebijakan, dan advokasi kebijakan, (Gilsinan, 1990 : 29). maka kebijakan kriminal dapat diartikan sebagai pembuatan, pelaksanaan dan advokasi kebijakan yang diambil oleh negara dalam rangka mengatasi masalah kejahatan. Pranata utama yang menghasilkan kebijakan kriminal meliputi lembaga legislatif, sistem peradilan pidana, dan lembaga-lembaga pembuat kebijakan yaitu berbagai lembaga birokrasi yang diberi kewenangan untuk mengatur hal-hal yang berhubungan dengan pengendalian kejahatan dengan berbagai bentuk (Mustofa, 2007: 44).

Dengan kata lain, kebijakan kriminal yang telah disahkan oleh negara, maka negara juga, sudah harus siap mengimplementasikan. Terkait dengan kebijakan kriminal dalam rangka mencegah kejahatan (seperti kejahatan seksual terhadap anak) dapat ditegorikan sebagai bentuk kebijakan Regulatory. Regulatory adalah kebijakan tentang pembatasanpembatasan atau larangan-larangan perbuatan bagi seseorang atau sekelompok orang. Batasan-batasan itu dimaksudkan untuk mengurangi kebebasan seseorang atau sekolompok orang untuk berbuat sesuatu (Irfan, 1999 : 104).

Kebijakan kriminal adalah suatu bentuk kebijakan yang diambil oleh negara untuk melakukan kriminalisasi terhadap suatu tindakan yang dianggap merugikan, serta strategi untuk menanggulanginya. Dengan merujuk pada tiga peran utama dari kebijakan: pembuatan kebijakan, pelaksanaan kebijakan, dan advokasi kebijakan. Maka kebijakan kriminal dapat diartikan sebagai pembuatan, pelaksanaan dan advokasi kebijakan yang diambil oleh negara dalam rangka mengatasi masalah kejahatan. Pranata utama yang menghasilkan kebijakan kriminal meliputi lembaga legislatif, sistem peradilan pidana, dan lembaga-lembaga pembuat kebijakan 
yaitu berbagai lembaga birokrasi yang diberi kewenangan untuk mengatur hal-hal yang berhubungan dengan pengendalian kejahatan dengan berbagai bentuk. (Mustofa, Kriminologi Kajian Sosiologi Terhadap Kriminalitas, Perilaku Menyimpang dan Pelanggaran Hukum, 2007 : 44).

Dengan kata lain, kebijakan kriminal untuk menanggulangi kejahatan-kejahatan seksual tidak harus selalu mengedepankan proses hukum yang berkaitan dengan SPP. Sarana-sarana lain pun diharapkan dapat berfungsi dan memberikan jalan keluar seperti menggunakan sarana non penal yang seringkali disebut sebagai pencegahan tanpa menggunakan pidana (prevention without punishment).

\section{Kebijakan Kriminal Dalam Rangka Mencegah Kejahatan Seksual}

Munculnya kejahatan-kejahatan berdimnsi baru yang bercirikan modern merupakan dampak negatif dari perkembangan yang sangat cepat dalam kejahatan seksual (pedofilia). Di Indonesia tengah berlangsung usaha untuk memperbaiki Kitab Undang-Undang Hukum Pidana (KUHP) sebagai usaha pembaharuan nasional yang bersifat universal (menyeluruh). Usaha pembaharuan hukum pidana di Indonesia tentunya tidak terlepas dari politik hukum yang bertugas untuk meneliti perubahanperubahan yang perlu diadakan terhadap hukum yang ada agar dapat memenuhi kebutuhan-kebutuhan baru di dalam masyarakat.

Politik hukum, tersebut meneruskan arah perkembangan tertib hukum dari "ius constitutum", yang tertumpu pada kerangka landasan hukum yang terdahulu menuju pada penyusunan "ius constituendum" atau hukum pada masa yang akan datang. Upaya pembaharuan hukum pidana di Indonesia yang sudah dimulai sejak UUD 1945 tidak dapat dilepaskan pula dari landasan sekaligus tujuan yang ingin dicapai oleh bangsa Indonesia, seperti yang telah dirumuskan dalam pembukaan UUD 1945 , yaitu "melindungi segenap bangsa Indonesia dan untuk mewujudkan kesejahteraan umum berdasarkan Pancasila" (Sudarto, 1974 : 2).

Kejahatan merupakan perbuatan antisosial yang meresahkan masyarakat dalam interaksi dengan sesamanya dimana perbuatan tersebut mendapat tantangan dari pemerintah atau negara, secara yuridis kejahatan dapat dikatakan sebagai perbuatan melawan hukum dimana sebagai akibat dari perbuatan itu, pelaku dapat dikenakan sanksi sebagaimana termasuk dalam peraturan undang-undang yang dilanggar tersebut (Bawengan, 1997: 22 ).

Seksualitas merupakan sebuah proses sosial budaya yang mempengaruhi hasrat atau birahi manusia, keberadaanya dipengaruhi oleh interaksi faktor-faktor biologis, psikologis, sosial ekonomi, ekonomi, politik, agama, dan spiritualitas. Seksualitas merupakan hal yang positif, berhubungan dengan jatidiri seseorang dan kejujuran seseorang terhadap dirinya. Sayangnya masyarakat umumnya masih melihat seksualitas sebagai hal negatif, bahkan tabu dibicarakan. Inilah yang membuat perbincangan pada ruang tertentu dan oleh kalangan tertentu pula (AD. Kusumaningtyas dan Achmad Nurcholils, 2015 : 9). Pelecehan seksual terhadap anak terjadi dalam banyak bentuk, dimana banyak korban kejahatan seksual dewasa ini yang disebabkan dari berbagai faktor, diantaranya:

1. Adanya orientasi ketertarikan seksual terhadap anak-anak (Pedofilia)

Pedofilia adalah manusia dewasa yang memiliki perilaku seksual 
menyimpang dengan anak-anak. Kata Pedofilia berasal dari bahasa paedo (paedo) philia (cinta) (Harapan, $2014:$ 3). Secara harfiah pedofilia berarti cinta pada anakanak. Akan tetapi, perkembangan kemudian, sehingga secara umum digunakan sebagai istilah untuk menerangkan salah satu kelainan perkembangan psikoseksual dimana individu memiliki hasrat erotis yang abnormal terhadap anak-anak. Anak-anak yang menjadi sasaran dari pemuas birahi seksual orangorang dewasa pengidap pedofilia adalah anak-anak usia pra-pubertas. Yaitu anak-anak yang belum mengalami menstruasi atau belum dapat dibuahi bagi anak perempuan dan belum dapat menghasilkan sperma bagi anak laki-laki (Yuwono, 2015 : 44 ). Penyebab dari munculnya penyakit ketertarikan kejahatan seksual ini, disebabkan oleh 2 (dua) hal, yaitu Pertama, akibat dari pengalaman masa yang didapatkan seorang anak yang tidak mendukung perkembangan kedewasaannya. Kedua, karena trauma pernah mendapatkan kekerasan seksual dari orang dewasa sewaktu masih anak-anak. Walaupun pedofilila merupakan merupakan salah satu penyakit kelainan psikoseksual, namun dimata hukum tetap tidak ada toleransi terhadap pelaku kejahatan seksual tersebut.

2. Pengaruh Pornomedia Massa

Kata Pornomedia berasal dari pecahan kata Prono yang berarti Cabul, dan media yang berarti alat (sarana). Jika dihubungkan pornomedia merupakan alat bantu atau sarana yang digunakan dalam mengekspos hal-hal yang bersifat cabul. Pada zaman modern sekarang ini (era globalisasi) memungkinkan orang dengan mudahnya mendapatkan sajian mengenai kehidupan seksual dengan gamblang. Mengingat bahwa pornografi merupakan salah satu bisnis komersial, yang mempunyai strategis jitu yang diterapkan dalam menjalankan bisnis komersial tersebut.

3. Ketidakpahaman Anak Akan Persoalan Seksualitas

Seksualitas mencakup banyak aspek, yaitu pikiran, perasaan, sikap, dan perilaku dirinya, sehingga proses pengajarannya harus dari dini.palilng tidak anak sudah dibekali aturan dan norma sosial yang berlaku sehingga dapat membedakan antara sikap pria dan wanita. Lambat laun anak-anak akan menganggap perilaku-perilaku tersebut sebagai hal-hal yang biasabiasa saja atau sebagai permainan. Dengan demikian keluarga sangat diperlukan dalam mengatasi masalah tersebut, dengan menanamkan standar moralitas terhadap anak-anak mereka dan memberikan pemahaman akan persoalan seksualitas sejak dini dapat dimulai dengan membiasakan etika dan sopan santun dalam pergaulan.

\section{Kontroversi Sanksi Kebiri dalam PERPPU No. 1 Tahun 2016 tentang Perlindungan Anak}

Kekerasan seksual terhadap anak merupakan kejahatan serius (serious crimes) yang semakin meningkat dari waktu ke waktu dan secara signifikan mengancam dan membahayakan jiwa anak, merusak 
kehidupan pribadi dan tumbuh kembang anak, serta mengganggu rasa kenyamanan, ketentraman, keamanan, dan ketertiban masyarakat.

Untuk merespon kekerasan seksual tadi, pemerintah menerbitkan PERPPU No 1 Tahun 2016 tentang Perlindungan Anak. Pererbitan PERPPU tadi mengubah atas Undang-Undang No 23 Tahun 2002 tentang Perlindungan Anak. Dalam UU No. 23 Tahun 2002 tentang Perlindungan Anak telah mengatur sanksi pidana bagi pelaku kekerasan seksual terhadap anak namun penjatuhan pidanan tadi belum memberikan efek jera dan belum mampu mencegah secara komprehensif terjadinya kekerasan seksual terhadap anak . untuk mengatasi fenomena kejahatan kekerasan seksual terhadap anak, maka perlu memberi efek jera kepada pelakunya (detterence) dan mencegah terjadinya kekerasan seksual terhadap anak. Dan Pemerintah menambah pidana pokok berupa pidana mati dan pidana seumur hidup, serta pidana tambahan berupa pengumuman identitas pelaku. Selain itu, perlu menambahkan ketentuan mengenai tindakan berupa kebiri kimia, pemasangan alat pendeteksi elektronik, dan rehabilitasi. Sehingga penerapan yang berlangsung dalam suatu kebijakan memerlukan adanya landasan yang benar dalam pendekatan normative yang dikelola dengan analisis yang benar untuk mendapatkan suatu pendekatan dasar hukum yang ingin didapatkan. Karena suatu hak asasi manusia merupakan hak yang melekat dan tak akan bisa dipisahkan dari suatu pengkajian yang mendalam terhadap dilematika kebutuhan manusia di dunia.

Dalam PERPPU No. 1 Tahun 2016 Tentang Perubahan Kedua atas UU No 23 Tahun 2003 Tentang Perlindungan Anak, pada Pasal 81 ayat (7) bahwa pelaku kejahatan seksual akan dikenakan sanksi berupa kebiri kimia dan pemasangan alat pendeteksi elektronik. Dan pada Pasal (9) menjelaskan sanksi kebiri akan dikecualikan bagi pelaku Anak. Selain itu, PERPPU tadi juga menjelaskan bahwa sanksi kebiri kimia diserta dengan rehabilitasi. Sementara pada Pasal 82 ayat (5), pelaku dapat dikenai pidana tambahan berupa pengumuman identitas pelaku dan ayat (6) pelaku dikenai tindakan berupa rehabilitasi dan pemasangan alat pendeteksi elektronik. Pengertian pengebirian terhadap pelaku kejahatan seksual terhadap anak adalah salah satu jenis sanksi pidana pernah diberlakukan di beberapa negara dengan tujuan melindungi masyarakat.

Sanksi kebiri dengan menyuntikkan zat kimia tertentu, disebut suntik kebiri atau kebiri kimiawi. Paling tidak ada dua obat yang secara umum digunakan, Obat cyproterone asetat umumnya digunakan untuk pengebirian kimia di seluruh Eropa. Sedangkan medroksiprogesteron asetat (MPA, bahan dasar sekarang digunakan dalam DMPA) adalah obat yang digunakan di Amerika. Dengan menyuntikkan obat antiandrogen, seperti medroxyprogesterone acetate atau cyproterone. Yakni Obatobatan yang dapat menekan fungsi hormon testosteron untuk menurunkan level testosteron, yakni hormon laki-laki, yang bertanggung jawab pada timbulnya libido.

a. Tinjauan Hak Asasi Manusia (HAM) Hak Asasi Manusia (HAM) adalah hak-hak yang dimiliki manusia semata-mata karena ia manusia, bukan karena bukan diberikan oleh masyarakat atau hukum positif melainkan berdasarkan martabatnya sebagai manusia. Dalam arti tersebut, meskipun manusia terlahir dengan warna kulit, jenis kelamin, bahasa, budaya, dan kewarganegaraan yang berbedabeda, maka ia tetap mempunyai hak- 
hak tersebut. Dalam hal ini HAM bersifat universal, selain itu hak-hak tersebut tidak dapat dicabut (inalianable),

Berkaitan dengan sanksi kebiri, bahwa si pelaku yang melakukan tindak kekerasan seksual pada anak dan dijatuhi sanksi pidana kebiri, dilihat dari sudut pandang HAM merupakan tindakan dalam rangka memberikan perlindungan hak asasi yang tidak dapat dikurangi (non derogable right) kepada si korban, yaitu hak dasar asasi si korban yang dianugerahi oleh Tuhan yaitu hak reproduksi, tetapi di sisi lain pemberian sanksi kebiri merupakan pengurangan atau pembatasan hak (derogable right) yang diberikan kepada si pelaku, karena sebagai konpensasi atas kesalahan perbuatan yang telah mengancam rasa aman dan tumbuh kembang anak. Selain itu, sanksi kebiri bertujuan untuk upaya pencegahan perilaku si pelaku ketika keluar dari penjara tidak lagi sebagai predator kekerasan seksual pada anak. Dengan demikian, hukuman kebiri dianggap sebagai pelanggaran HAM karena hasrat seksual adalah sesuatu yang melekat dalam diri manusia yang tidak boleh dihilangkan. Dalam pandangan HAM bahwa sanksi kebiri dianggap sebagai pelanggaran HAM karena hasrat seksual adalah sesuatu yang melekat pada diri manusia yang tidak dapat dihilangkan atau hak yang tidak boleh dibatasi (non derogable right).

b. Tinajauan Kesehatan (Medis)

Dalam dunia kesehatan, dokter merupakan tenaga kesehatan merupakan profesi yang sangat membanggakan pada sebagian besar masyarakat. Seorang dokter harus senantiasa mengingat kewajibannya melindungi hidup makhluk insani, mempergunakan segala ilmu dan keterampilannya untuk kepentingan pasien. Berkaitan dengan hal ini, hukuman kebiri tidak efektif apabila dikaitkan dengan kesehatan, lebih baik sekalian diberi hukuman mati daripada kebiri, sebab kebiri menimbulkan dampak-dampak buruk tertentu bagi kesehatan terhukum yang membebaninya di kemudian hari. Bahwa Kode Etik Profesi Dokter menolak secara tegas untuk menjadi eksekutor kebiri, karena dokter bertugas untuk menyembuhkan suatu penyakit, bukan untuk memberi penyakit. Selain itu, tugas dan kewajiban hukum tenaga medis atau dokter telah diatur dalam undang-undang Nomor 36 tahun 2009 tentang kesehatan. Di dalam Pasal 51 Undang-Undang Nomor 29 Tahun 2004 Tentang Praktik Kedokteran diatur mengenai kewajiban dokter, yaitu, memberikan pelayanan medis sesuai dengan standar profesi dan standar prosedur operasional serta kebutuhan medis pasien. Pengaturan mengenai kewajiban dokter diatur lebih lanjut di dalam Pasal 58 Ayat (1) Undang-Undang Nomor 36 Tahun 2014 Tentang Tenaga Kesehatan, yaitu: memberikan pelayanan kesehatan sesuai dengan standar profesi, standar pelayanan profesi, standar prosedur operasional, dan etika profesi serta kebutuhan kesehatan penerima pelayanan kesehatan.

c. Tinjauan Hukum Islam 
Ajaran Islam yang berlandaskan alQur'an dan sunnah nabi Muhammad Saw, tidak sekedar merupakan sebuah sistem yang konprehensif dalam mengatur semua aspek, tetapi juga bersifat universal yang senantiasa sesuai dengan dinamika kehidupan. Ajaran Islam memiliki hubungan yang erat dan integral dengan kehidupan masyarakat, termasuk di dalamnya kehidupan bermasyarakat, berpolitik, hukum, pendidikan, dan persoalanpersoalan patologi sosial (seperti kejahatan). Islam bukanlah agama sekuler yang memisahkan agama dengan fenomena sosial. Dan Islam bukanlah hanya sekedar membicarakan spritualitas atau ritualitas. Lebih dari itu, Islam merupakan serangkaian keyakinan, ketentuan dan peraturan serta tuntutan moral bagi setiap aspek kehidupan manusia. Islam memandang, bahwa dengan mempraktekkan ajaran Islam adalah sebagai suatu jalan hidup yang melekat pada setiap aktivitas kehidupan, baik yang terkait ritual dengan Tuhan maupun ketika manusia berinteraksi dengan sesama manusia. Dalam pandangan Islam, tujuan hidup seorang Muslim adalah kebahagian di dunia dan di akhirat. Dua kebahagian itu akan tercapai apabila seseorang manusia (hamba) sepenuhnya taat kepada Allah. Oleh karena itu, manusia selalu merasakan akan kebutuhan terhadap Allah. Dengan demikian, seseorang individu tidak akan berperilaku sesuka hati, termasuk berperilaku jahat atau mencelakakan orang lain (memberi mudharat). Dengan memperkuat dan memperkokoh berbagai macam aspeknya di satu sisi, serta melakukan berbagai upaya preventif (agar tidak menjadi korban kejahatan) dan tindakan refresif (terhadap pelaku kejahatan) di sisi lain, sehingga maqashid nya tidak hilang dan tetap dapat menjamin rasa aman dan tenteram bagi semua pihak. Meskipun kebutuhan dan hajat kehidupan manusia yang terus berubah.

d. Respon Hukum Fiqih Terhadap Sanksi Pelaku Kejahatan Seksual

Dalam referensi buku-buku fiqih perbuatan jarimah atau perbuatan jahat dikelompokkan dalam tiga kategori. Pertama, Jarimah Qishas. Terdiri dari jarimah pembunuhan dan jarimah penganiayaan. Kedua, Jarimah Hudud. Yaitu, perbuatan zina, menuduh muslimah baik-baik berbuat zina (qadzf), meminum minuman keras (syurb al-khamr), pemberontakan (al-baghyu), murtad (al-riddah), pencurian (alsariqah), dan perampokan (alhirabah). Ketiga, Jarimah Ta'zir. Yaitu semua tindakan kejahatan yang belum diatur secara jelas oleh kitab suci (Qur'an dan Sunnah). Sementara aturan teknisnya baik jenis maupun pelaksanaannya ditentukan oleh penguasa setempat. Bentuk kejahatan dalam kategori ini sangat banyak dan tidak terbatas, sesuai dengan kejahatan yang dilakukan dan termasuk korban yang ditimbulkannya.

Diantaranya, Kejahatan Kekerasan, Kejahatan Narkotika, Kejahatan Kekerasan Seksual. Terkait dengan eksistensi nilai-nilai maslahah dalam sanksi kebiri yang diterbitkan pemerintah dalam bentuk PERPPU 
Nomor 1 tahun 2016. Tujuan dari hukuman syari'at Islam adalah realisasi dari hukum islam itu sendiri, yakni sebagai pembalasan perbuatan jahat pencegahan secara umum dan khusus serta perlindungan dari hak-hak si korban. Sehingga pemidanaan dimaksudkan untuk mendatangkan kemslahatan umat dan mencegah kezaliman dan kemudaratan. ${ }^{1}$ Bekaitan dengan kejahatan pemerkosaan, hanya orang yang melakukan pemaksaan saja (pelakua kekerasan seksual) yang dijatuhi hukuman hadd, namun ada sebagian pendapat yang menyatakan bahwa sanksi kebiri terhadap pelaku kejahatan seksual dikategorikan sebagai tindakan yang sadis dan masuk dalam delik hirabah.

\section{PENUTUP}

\section{Kesimpulan}

Bahwa maraknya kejahatan seksual di tengah-tengah masyarakat, baik itu yang dilakukan oleh orang yang berorientasi seksual menyimpang (pedofilia) maupun yang di lakukan oleh orang yang dengan kesengajaan atau karena faktor lain seperti kasus Yuyun. Dan sanksi bagi pelaku kejahatan seksual terhadap anak perlu penanggulangan khusus dengan menerbitkan kebijakan kriminal (criminal policy) dengan memberi sanksi berat dan membuat jera (detterence) pelaku. Kebijakan kriminal tadi ditandai dengan terbitnya PERPPU No. 1 Tahun 20016 tentang Perlindungan Anak. Penerbitan PERPPU ini mengubah atas UndangUndang No 23 Tahun 2002 tentang

\footnotetext{
${ }^{1}$ Makrus Munajat, Dekonstruksi Hukum Pidana Islam, Jogjakarta: Logung, 2004, hal. 39.
}

Perlindungan Anak. Dan dalam PERPPU No. 1 Tahun 2016 Tentang Perubahan Kedua atas UU No 23 Tahun 2003 Tentang Perlindungan Anak, pada Pasal 81 ayat (7) bahwa pelaku kejahatan seksual akan dikenakan sanksi berupa kebiri kimia dan pemasangan alat pendeteksi elektronik. Upaya Pemerintah untuk menanggulangi kejahatan seksual terhadap anak melalui PERPPU No. 1 Tahun 2016 tentang Perlindungan Anak dengan memberi sanksi kebiri kimiawa kepada pelaku dengan harapan menimbulkan efek jera ternyata tidak diamini oleh semua komponen masyarakat.

\section{Saran}

Seharusnya dengan melihay banyak diantara komponen masyarakat tidak setuju atas keebijakan kebiri kimiawi kepada pelaku kejahatan. Respon ketidak setujuan sanksi kebiri kimiawi tadi dating dari penggiat Hak Asasi Manusia (HAM) kalangan Paramedis, dan respon Hukum Islam. Dari kalangan penggiat HAM misalnya, mengacu ketentuan UndangUndang Nomor 39 Tahun 1999 tentang Hak Asasi Manusia pada Pasal 1 Ayat (1) (dalam ketentuan umum) menyatakan bahwa HAM adalah seperangkat hak yang melekat pada hakikat dan keberadaan manusia sebagai makhluk Tuhan Yang Maha Esa dan merupakan anugerah-Nya yang wajib dihormati, dijunjung tinggi dan dilindungi oleh negara, hukum, dan pemerintah, dan setiap orang demi kehormatan serta perlindungan harkat dan martabat manusia. Selain itu, dalam dunia medis, khususnya profesi dokter adalah memberikan tindakan terhadap orang sakit agar sembuh dan sehat. Dan dokter disumpah Bukan memberikan suntikan kimiawi terhadap orang yang sehat agar menurun kesehatannya. Dan hukum Islam menyampaikan bahwa menciptakan dan 
menjaga kemaslahatan dan menghindari dari segala hal yang merugikan, baik merugikan diri sendiri maupun orang lain, termasuk merugikan pisik, psikis, atau kerugian materi adalah perintah ajaran Islam. Upaya menjaga atau memelihara kondisi seperti inilah yang disebut maqashid al-syariah. Para ulama mengklasifikasikan bahwa tujuan maqashid al-syariah adalah bertujuan memelihara agama (al-din) dan diri (nafs), akal pikiran (aql), harta (mal), dan keturunan (nasl).

\section{DAFTAR PUSTAKA}

Alston, Philip dan Frans Magnis Suseno, 2008. Hukum Hak Asasi Manusia, Yogyakarta. PUSHAM UII

Arikunto, Suharsimi, 2005, Manajemen Penelitian. Jakarta. Rineka Cipta.

Bawengan, Gerson W.,1997, Pengantar Psikologi Kriminil, Jakarta: Pradnya Paramita. Berita Antara 5 April 2014.

Djazuli, H.A., (2007), Fiqh Siyasah: Implementasi Kemaslahatan Umat dalam Rambu- Rambu Syariah, Jakarta, Kencana.

F. James Gilsinan,1990, Criminology and Public Policy An Intoduction, Englewood Cliffs: Prentice Hall.

Hasan El Qudsy, 2012, Ketika Anak Bertanya Tentang Seks, Cet. I, Solo: Tinta Media.

Irfan, H.M. Nurul, 2013, Fiqh Jinayah, Jakarta: AMZAH.

Kansil, C.S.T, 1988, Pengantar Ilmu Hukum dan Tata Hukum Indonesia, Jakarta: Bina Aksara.

Kusumaningtyas, AD dan Achmad Nurcholils, dkk, 2015, Seksualitas dan Agama: Kesehatan Reproduksi Dalam Perspektif Agama-Agama, Jakarta: Gramedia, 2015.

Lubis, Junaidi, (2010), Islam Dinamis Model Ijtihad al-Khulafa al-
Rasyidun dalam Konteks

Perubahan Masyarakat. Jakarta, Dian Rakyat.

M Islamy Irfan, 1999, Prinsip-Prinsip Perumusan Kebijaksaanaan Negara, Jakarta: Bumi Aksara.

Muladi, 1995, Kapita Selekta Sisitem Peradilan Pidana, Semarang: Undip.

Mustofa, Muhammad, 2007, Kriminologi Kajian Sosiologi Terhadap Kriminalitas, Perilaku Menyimpang dan Pelanggaran Hukum, Depok: Fisip UI Press.

Zainuddin, Muhammad, Kebijakan Hukum Dalam Rangka Penanggulangan Kejahatan Pedofilia, Semarang: Tesis Magister Ilmu Hukum Universitas Diponegoro, 2007

Reza Fajri Hidayat, Penerapan Hukuman Kebiri bagi Pelaku Kejahatan Kekerasan Seksual Terhadap Anak (Kajian Hukum Islam atas PERPPU Nomor 1 Tahun 2016). Skripsi. Fakultas Syariah dan Hukum UIN Syarif Hidayatullah. Jakarta. 2017

MP, Muhamad Rezky Pahlawan. "PERLINDUNGAN HUKUM TERHADAP ANAK YANG MENJADI KORBAN KEKERASAN TELAAH BERDASARKAN HAK ASASI MANUSIA." Jurnal Surya Kencana Satu: Dinamika Masalah Hukum dan Keadilan 9.1 (2018): 125-138.

Siagian, Amrizal, 2015, Pengantar Studi Ilmu Kriminologi, Jakarta: UIN Jakarta Press.

Sudarto, 1974, Suatu Dilema Dalam Pembaharuan Sistem Pidana di Indonesia, Semarang: Pusat Studi FH Undip.

Sudarto, 1983, Hukum Pidana dan Perkembangan Masyarakat", Jakarta: Sinar Baru. 
Sudarto, 1997, Hukum dan Hukum Pidana, Bandung: Alumni.

Syatibi, Abu Ishaq, 1997, Al Muwafaqat fi Ushul Asy Syariah, Beirut: Dar Ibn Affan.
Yin, Robert K., 1996, Studi Kasus Desain \& Metode, Jakarta, Rajawali Pers.

Yuwono, Ismantoro Dwi, 2015 Penerapan Hukum Dalam Kasus kekerasan Seksual Terhadap Anak, Cetakan I, Yogyakarta 